\title{
LIETUVOS AKUŠERIŲ-GINEKOLOGŲ PATIRTIS VERTINANT NĖŠČIOSIOS SVEIKATOS BŪKLĘ, SUSIJUSIĄ SU DARBO SĄLYGOMIS
}

\author{
Aušra Tartilaitė-Paulauskienė, Ramunė Miežanskienė \\ Kauno technologijos universitetas, Socialiniu ir humanitariniu moksly ir menu fakultetas, \\ Viešosios politikos ir administravimo institutas
}

Raktažodžiai: gydytojai akušeriai-ginekologai, něščiosios, darbo sąlygos.
Santrauka
Tinkamas néščiosios kenksmingų darbo sąlygų identifikavimas vizito pas gydytoją akušerị- gine- kologą metu yra išskirtinai svarbus besilaukiančios moters ir jos vaisiaus sveikatai - tai patvirtina įvai- rių šalių mokslininkų atlikti tyrimai.
Tyrimo tikslas: atskleisti Lietuvos akušerių-gineko- logų patirtị vertinant néščiosios sveikatos būklę, su- sijusią su darbo sąlygomis.
Tyrimo metodas ir aprašymas. Siekiant užsibrèžto tyrimo tikslo $2016 \mathrm{~m}$. lapkričio ménesị buvo atlikta dviejų gydytojus akušerius-ginekologus vienijančių draugijų narių anoniminè anketinė apklausa. Iš 582 narių tyrime dalyvavo 99 respondentai.
Gauti rezultatai. Tyrimo rezultatai atskleide, kad net 42 proc. respondentų patiria problemų renkant nėščiosios anamnezę. Darbo sąlygas išsamiai ap- taria 44,8 proc. respondentų; 43,8 proc. apklaustų- jų nurodè, kad darbo sąlygų aptarimas su néščiaja priklauso nuo aplinkybių. Per 80 proc. apklaustujų patiria vidinius prieštaravimus išduodant nedarbin- gumo pažymėjimus. Daugiau kaip pusè responden- tų, spręsdami nedarbingumo pažymėjimo išrašymo néščiajai klausimą, susiduria su probleminèmis si- tuacijomis.
Išvados. Dalis Lietuvos gydytojų akušerių-gineko- logų néščiujų darbo sąlygų aptarimą vertina subjek- tyviai. Tokia situacija siejama su tuo, jog Lietuvos teisès aktuose nèra detalios metodikos, kokia apim- timi reikètų domètis něščiujų darbo sąlygomis. Gy- dytojai akušeriai-ginekologai, išduodami nedarbin- gumo pažymejjimus, gana dažnai susiduria su atve- jais, kada turi spręsti nemedicininio pobūdžio nèš-

čiujų problemas, todèl atskirais atvejais būtų naudinga bendradarbiauti su valstybès ir kitomis institucijomis bei organizacijomis, kurios padètų nèščiosioms ịgyvendinti jų teises darbo santykiuose.

\section{Ivadas}

Kiekvienam darbuotojui privalo būti užtikrintos saugios ir sveikatai nekenksmingos darbo sąlygos, tačiau kai kurioms darbuotojų kategorijoms turi būti taikoma ypatinga apsauga. Viena iš šių darbuotojų kategorijų - nëščios darbuotojos. Jeigu joms neužtikrinamos sveikos darbo sąlygos, tai gali turèti neigiamos įtakos ne tik jų pačių sveikatos būklei, bet ir skaudžių pasekmių ị pasauli ateinančiai gyvybei. Pas gydytojus akušerius-ginekologus apsilanko ivvairių profesijų ir specialybių darbuotojos. Šie gydytojai išduoda darbuotojoms pažymas apie jų néštumą, skirtas darbdaviams; savo ruožtu darbdaviai privalo užtikrinti darbuotojoms saugias ir nekenksmingas darbo sąlygas. Deja, Lietuvoje atlikti tyrimai rodo, kad kai kurios darbuotojos nežino savo elementarių teisių (12). Pabrèžtina, kad pagal Lietuvos teisinę praktiką, darbdavio informavimas apie néštumą yra besilaukiančios darbuotojos teisé, bet ne pareiga (7). Todèl tinkamas kenksmingų darbo sąlygų identifikavimas vizito pas gydytoją metu ir aktyvus gydytojo vaidmuo konstatavus darbo sąlygų netinkamumą yra išskirtinai svarbus. Remdamiesi atliktų tyrimų duomenimis, kitų šalių mokslininkai pastebi, kad darbo sąlygos gali neigiamai veikti nėščiosios sveikatą, todèl yra būtina kuo anksčiau aptarti darbo sąlygų reikšmę ir jų ịtaką něštumui (4). Šios aplinkybès lemia poreiki ištirti, kokia gydytojo akušerio-ginekologo patirtis Lietuvoje vertinant něščiosios sveikatos būklę, susijusią su darbo sąlygomis. Pastebėtina, kad iki šiol nacionaliniu mastu tokių tyrimų nėa atlikta, nors šie tyrimai periodiškai atliekami daugelyje kitų užsienio valstybių - Lenkijoje, Švedijoje, Danijoje, Norvegijoje.

Moksliniai tyrimai patvirtina, jog něščiujjų nedarbingu- 
mo fakto konstatavimui lemiamos reikšmès turi ne tik ịvairios nèščiosios medicininès būklès, bet ir jų darbo sąlygos. Lenkijoje, Norvegijoje bei Danijoje atlikti tyrimai atskleidè grupę veiksnių, kurie yra reikšmingai susiję su nėščiosioms nustatomu nedarbingumu. Tarp jų - ne tik sveikatos būklès, socialiniai-ekonominiai, bet ir su darbo sąlygomis susiję veiksniai, tai yra darbo pasiekiamumas viešuoju transportu, ilgos darbo valandos (13), darbo santykiuose kilusios konfliktinès situacijos (1), nepatogios darbo padètys (laikysena), svorių kilnojimas bei pamaininis darbas (3).

Akušeriui-ginekologui tenka ịvertinti j̣vairias su nèščiosios darbu susijusias rizikas, tačiau ne visos jos akivaizdžios. Pavyzdžiui, ne tik fiziškai sunkus darbas gali turèti žalingą poveikị něščiajai, bet ir toks, kuris sukelia psichologines itampas. Tyrimai $(13,1,3)$ nustato, kad itampa darbo vietoje yra tiesiogiai susijusi su nedarbingumo nustatymo faktu. Taip pat teigiama, kad moterys, esant priešlaikinio gimdymo rizikai, turètų būti atidžiai stebimos, o jei darbe patiriamas stresas, jis turètų būti sumažinamas arba pašalinamas, nes tokio pobūdžio darbas padidina persileidimo, priešlaikinio gimdymo, priešlaikinio gimimo, mažo naujagimio svorio ir preklamsijos rizikas (5). Minèta situacija gali sąlygoti ịvairius iššūkius gydytojų akušerių-ginekologų darbe, nes něščiosios nedarbingumas konstatuojamas remiantis išskirtinai medicininiais kriterijais. Pavyzdžiui, Švedijoje atliktos gydytojų akušerių ir ginekologų apklausos atskleidžia, kad didžioji dauguma pacienčių prašo konstatuoti nedarbingumą ne dèl medicininių priežasčių (2, 6). Tokia situacija yra ịvardijama vienu pagrindinių gydytojų akušerių-ginekologų iššūkiu. Taip pat susiduriama su iqvairiais kitais iššūkiais konstatuojant nėščiosios nedarbingumą, tarp kurių pagrindiniais įvardijami šie: „labai sunku“ arba „gana sunku“ nustatyti néščiosios nedarbingumą ar darbingumo sumažèjimą, taip pat problemiškas konfliktų, kilusių dẻl nedarbingumo nustatymo nëščiosioms, sprendimas (2). Nenorèdami konfliktuoti, Švedijos gydytojai dažnu atveju yra linkę sutikti su něšciujų pageidavimais (6). Reikètų atsižvelgti ị tai, jog užsienio šalių praktika atspinti bendras tendencijas, tačiau jos yra neatskiriamos nuo šalies teisinio, socialinio ir ekonominio konteksto.

Lietuvoje nèra išsamiai analizuota praktika, susiklostanti akušeriams-ginekologams vertinant néščiosios darbo sąlygų ịtaką jos sveikatos būklei.

Tyrimo tikslas: atskleisti Lietuvos akušerių-ginekologu patirtị vertinant néščiosios sveikatos būklę, susijusią su darbo sąlygomis.

\section{Tyrimo medžiaga ir metodas}

Remiantis Visuomenès sveikatos stebėsenos duomenu fondo informacija, $2015 \mathrm{~m}$. Lietuvoje pagrindiniame darbe dirbo 647 akušeriai-ginekologai (14). Siekiant užsibrěžto tyrimo tikslo $2016 \mathrm{~m}$. lapkričio ménesį buvo atlikta dviejų gydytojus akušerius -ginekologus vienijančių draugijų narių anoniminè anketinè apklausa. Abi draugijos vienija 582 narius. Klausimyną sudare dvi pagrindinès dalys. Pirmoje klausimyno dalyje respondentų buvo prašoma pateikti savo individualius duomenis (lytis, darbovietes duomenys, darbo su besilaukiančiomis pacientemis stažas). Antrają klausimyno dali sudarè klausimai, susiję su respondentų patirtimi vertinant něščiu pacienčių būklę, susijusią su jų darbo sąlygomis.

Tyrimo aprašymas. Iš 582 respondentų populiacijos, tyrime dalyvavo 99 respondentai. Gauti rezultatai yra reprezentatyvūs, kada taikomas $95 \%$ patikimumo lygmuo su 9\% paklaida. Gautų duomenų statistinè analizè buvo atlikta naudojant IBM SPSS v.23 programinị paketą. Didžiąą respondentų dalị sudare moterys (87,6 proc.). Daugiau kaip 90 proc. apklaustujų ( 91,7 proc.) turi daugiau kaip 10 metų darbo su néščiomis pacientemis patirtí. Didžioji dauguma respondentų dirba viešame sektoriuje ( 87,4 proc.), daugiau kaip pusé - privačiame (52,6 proc.). Beveik pusè respondentu ( 48,7 proc.) dirba abiejuose sektoriuose. Tyrimo ribotumai: tyrimo rezultatai yra reprezentatyvūs dviejų akušerių-ginekologų draugijų populiacijai, kurios narių skaičius sudaro 89,95 \% visų akušerių -ginekologų skaičiaus.

\section{Rezultatai ir jų aptarimas}

Kenksmingos sąlygos ir pavojingi veiksniai darbo procese bei darbo aplinkoje gali sąlygoti ịvairius sveikatos sutrikimus, pakenkti vaisiui, todèl néščiosios darbo sąlygas svarbu išsiaiškinti jau pirmojo besilaukiančios moters apsilankymo pas gydytoją akušerį -ginekologą metu. Tyrimo rezultatai atskleide, kad net 42 proc. respondentu patiria problemų renkant nėščiosios anamnezę. Dažniausiai pasitaikantys nesklandumai - laiko stoka anamnezès surinkimui (22,7 proc.) bei administracinè našta / didelis darbo krūvis (19,6 proc.). Kai kurie respondentai susiduria su néščiosios nenoru suteikti informaciją (13,4 proc.), nepakankamai konkrečiais / aiškiais reikalavimais, keliamais anamnezės turiniui $(8,2$ proc.); atskirai buvo paminètos ir kitokios probleminès situacijos: „linkusios meluoti“" (pacientes - aut. past.); „moterys neprisimena daug ko“; „pacientès mažai apie save žino".

Nėščioms, neseniai pagimdžiusioms ar krūtimi maitinančioms moterims kenksmingų darbo sąlygų ir pavojingų veiksnių sąrašas yra patvirtintas Lietuvos Respublikos Vyriausybès 2015 m. gegužès 27 d. nutarimu Nr. 510 (11). Néšciosios darbo sąlygos privalo būti nurodytos pildant Nèštumo eigos įrašus - statistineje formoje Nr. 025-111/a (8). Nėščiųų, gimdyvių ir naujagimių sveikatos Aprašo 1 
priede - Něščiujų sveikatos tikrinimo reikalavimų 6 pastaboje yra numatyta, kad su něščiaja turi būti aptariami gyvenimo ir darbo sąlygų klausimai (9). Pastebètina, kad Lietuvos medicinos normoje MN 64:2008 „Gydytojas akušeris -ginekologas. Teisès, pareigos, kompetencija ir atsakomybë“ ịpareigojimas domètis pacienčiu darbo sąlygomis nèra ịrašytas; minètoje normoje apsiribojama gydytojo akušerio -ginekologo teisès iš įvairių institucijų gauti informaciją apie paciento gyvenamosios vietos ekologinę būklę, mokymosi, gyvenimo ir darbo sąlygas nustatymu (10). Siekiant išsiaiškinti, kiek detaliai gydytojai akušeriai -ginekologai aiškinasi galimas rizikas besilaukiančios moters darbe, respondentams buvo užduotas klausimas „Ar néščiosios konsultacijos metu domitès jos darbo sąlygomis?“. Darbo sąlygas išsamiai aptaria 44,8 proc. respondentų. Beveik toks pat skaičius apklaustujų ( 43,8 proc.) nurode, kad darbo sąlygų aptarimas su néščiaja priklauso nuo aplinkybiu (laiko, něšciosios atvirumo ir kt.). Kiti respondentai ịvardijo, kad išsamiai aptarti darbo sąlygas nepakanka laiko $(8,3$ proc.) arba/ir šių sąlygų aptarimas nèra prioritetinè anamnezès sritis (7,3 proc.).

Kai anamnezès rinkimo metu paaiškèja, kad néščioji dirba jai ir vaikui (vaisiui) kenksmingomis ar nepalankiomis darbo sąlygomis, didžioji dalis respondentų $(79,4)$ informuoja něšciają apie jos teisę nedirbti kenksmingomis darbe sąlygomis, ìspejja apie galimą riziką (71,1 proc.), taip pat pataria néščiajai kreiptis i darbdavi (70,1 proc.). Tik 1 proc. respondentų patare néščiajai kreiptis ị valstybès institucijas. Tai rodo, kad nèra bendradarbiavimo su darbuotojų saugą ir sveikatą kontroliuojančia institucija, nors dalis respondentų (9,5 proc.) pripažįsta, kad būtų naudinga bendradarbiauti su Valstybine darbo inspekcija. Tokio bendradarbiavimo poreikị atskleidžia pasirinktos temos, kuriomis respondentai norètu papildyti esamas kompetencijas ar iggyti naujų žinių (1 paveikslas), tai yra žinios apie darbdavio įsipareigojimus ir atsakomybę, susijusią su néščiosios darbo sąlygomis (60 proc.), valstybès institucijų

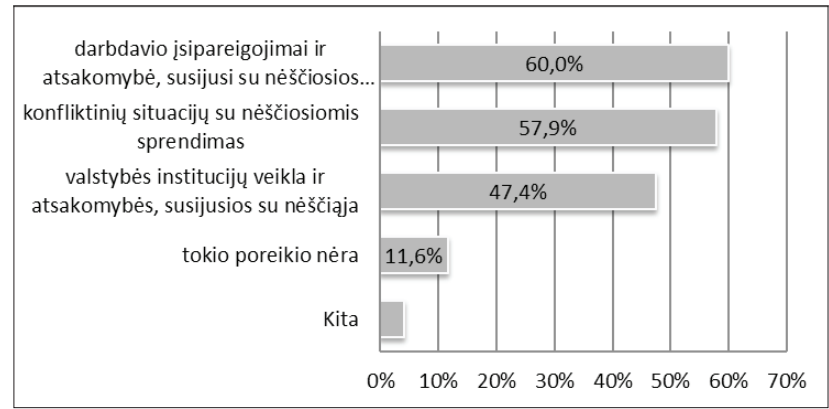

1 pav. Temų, kuriose gydytojai akušeriai-ginekologai norètų praplèsti kompetencijas pasiskirstymas veiklą ir atsakomybes, susijusias su nėščiaja (47,4 proc.) ir kt. Dalis respondentų darbo kenksmingomis sąlygomis problemą sprendžia išduodami ar rekomenduodami išduoti šeimos gydytojui laikino nedarbingumo pažymėjimą (13,4 proc.), tai yra nedarbingumo pažymėjimai išrašomi nesant konkrečios medicininès diagnozès.

Něščiosios nedarbingumo konstatavimas - daugelio gydytojų akušerių -ginekologų darbo neatsiejama dalis. Tyrimo rezultatai parodé, kad per 90 proc. respondentų $(96,1$ proc.) dažniau ar rečiau susiduria su atvejais, kai besilaukiančiai pacientei nustatomas laikinasis nedarbingumas bent keletą kartų per nėštumą iki néštumo ir gimdymo atostogu pradžios. Atsižvelgiant ị tai, apklausos metu buvo siekiama išsiaiškinti, kokias problemas akušeriai -ginekologai patiria konstatuojant, kad něščioji yra laikinai nedarbinga. Per 80 proc. apklaustujų dažniau ar rečiau patiria vidinius prieštaravimus išduodant nedarbingumo pažymėjimą (ver-

1 lentelè. Gydytojų akušerių -ginekologų patirtis probleminėse situacijose išduodant nedarbingumo pažymejjimus něščiosioms

\begin{tabular}{|c|c|c|}
\hline \multirow{4}{*}{$\begin{array}{l}\text { Ar susiduriate su atvejais kai } \\
\text { néščioji atsisako nedarbingu- } \\
\text { mo pažymèjimo? }\end{array}$} & Dažnai & $9,3 \%$ \\
\hline & Kartais & $53,6 \%$ \\
\hline & Retai & $33,0 \%$ \\
\hline & Niekada & $4,1 \%$ \\
\hline \multirow{4}{*}{$\begin{array}{l}\text { Nėščiosios pervertina savo } \\
\text { darbines galimybes }\end{array}$} & Sutinku & $22,7 \%$ \\
\hline & $\begin{array}{l}\text { Labiau sutinku } \\
\text { nei nesutinku }\end{array}$ & $39,2 \%$ \\
\hline & $\begin{array}{l}\text { Labiau nesutinku } \\
\text { nei sutinku }\end{array}$ & $33,0 \%$ \\
\hline & Nesutinku & $5,2 \%$ \\
\hline \multirow{4}{*}{$\begin{array}{l}\text { Ar patiriate psichologinį } \\
\text { spaudimą iš nėščiosios išduo- } \\
\text { ti nedarbingumo pažymėjimą } \\
\text { dèl kitų priežasčių, nei ne- } \\
\text { galejjimas dirbti dėl ligos ar } \\
\text { sužeidimo? }\end{array}$} & $\begin{array}{l}\text { Bent kartą per } \\
\text { savaitę }\end{array}$ & $4,1 \%$ \\
\hline & $\begin{array}{l}\text { Kartą ar keletą } \\
\text { kartų per mėnesị }\end{array}$ & $16,5 \%$ \\
\hline & $\begin{array}{l}\text { Kartą ar keletą } \\
\text { kartų per metus }\end{array}$ & $52,6 \%$ \\
\hline & $\begin{array}{l}\text { Niekada, arba } \\
\text { beveik niekada }\end{array}$ & $26,8 \%$ \\
\hline \multirow{4}{*}{$\begin{array}{l}\text { Nedarbingumo pažymėjimai } \\
\text { néščiosioms kartais išduo- } \\
\text { dami ne dèl ligos, o dèl kitų } \\
\text { priežasčių }\end{array}$} & Sutinku & $34,0 \%$ \\
\hline & $\begin{array}{l}\text { Labiau sutinku } \\
\text { nei nesutinku }\end{array}$ & $35,1 \%$ \\
\hline & $\begin{array}{l}\text { Labiau nesutinku } \\
\text { nei sutinku }\end{array}$ & $23,7 \%$ \\
\hline & Nesutinku & $7,2 \%$ \\
\hline \multirow{4}{*}{$\begin{array}{l}\text { Ar jaučiate valstybės institu- } \\
\text { cijų ar vadovybės spaudimą } \\
\text { išduoti mažiau nedarbingumo } \\
\text { pažymėjimų néščiosioms? }\end{array}$} & Dažnai & $6,3 \%$ \\
\hline & Kartais & $11,5 \%$ \\
\hline & Retai & $20,8 \%$ \\
\hline & Niekada & $61,5 \%$ \\
\hline
\end{tabular}


tinat něščiosios poreikius ir oficialius reikalavimus nedarbingumui nustatyti). Šiuos prieštaravimus paaiškina ir detalizuoja tolimesni apklausos rezultatai (1 lentelè).

Net 96 proc. respondentų susiduria su atvejais, kai nèščioji atsisako nedarbingumo pažymèjimo dèl ịvairių priežasčių (finansinių motyvų, darbdavio galimai neigiamo požiūrio ir pan.). 61,5 proc. apklaustujų su šia situacija susiduria kartą ar keletą kartų per metus, beveik 21 proc. kartą ar keletą kartų per mėnesí. Taip pat didesnè dalis respondentų linkę manyti, kad nėščiosios pervertina savo darbines galimybes (dirba intensyviau nei rekomenduotina) 61,9 proc. Pastebėtina, kad gydytojų akušerių-ginekologu praktikoje pasitaiko ir priešingų, negu aukščiau įvardinta, situacijų: 73,2 proc. respondentų patiria psichologinį besilaukiančios moters spaudimą išrašyti nedarbingumo pažymèjimą dèl kitų priežasčių nei negalèjimas dirbti dèl ligos ar sužeidimo. Didesnè dalis apklaustujų su tokiu pacienčių elgesiu susiduria kartą ar keletą kartų per metus (52,6 proc.), dalis - kartą ar keletą kartų per mènesị (16,5 proc.), kai kurie respondentai patiria psichologini néščiuju spaudimą bent kartą per savaitę ( 4,1 proc.). Dauguma respondentų (69,1 proc.) sutinka su teiginiu, kad nedarbingumo pažymėjimai nëščiosioms kartais išduodami ne dèl ligos, o dèl kitų priežasčių (socialinių, ekonominių ar kt.) Galima teigti, kad néččiujų lūkesčiai ir subjektyvus savo galimybių vertinimas yra iššūkis, nesusijęs su medicininiais aspektais, reikalaujantis išskirtinių kompetencijų akušerio -ginekologo darbe. Šių kompetencijų poreikị patvirtina daugumos apklaustųjų pageidavimas igyti naujų žinių priimant sprendimus konfliktinèse situacijose su néščiosiomis (57,9 proc.). Apklausos duomenys taip pat atskleide, kad net 38,5 proc. respondentų jaučia valstybės institucijų ar vadovybės spaudimą išduoti mažiau nedarbingumo pažymėjimų nèščiosioms. Aukščiau išvardyti sunkumai galimai sąlygoja respondentų nuomonę, kad turètų būti sudaromos galimybès néščiosioms suteikti dalinio nedarbingumo pažymèjimą: vienareikšmiškai su tuo sutinka 59,4 proc. respondentų, labiau sutinka negu nesutinka -25 proc. respondentų. Atkreiptinas demesys, kad Lietuvoje dalinio nedarbingumo konstatavimo galimybè nèra numatyta.

\section{Išvados}

1. Gydytojo akušerio-ginekologo vaidmuo identifikuojant něščiosios darbo sąlygas ir priimant sprendimus dèl tolimesnių veiksmų gali reikšmingai paveikti tolimesnę besilaukiančios moters sveikatos būklę. Dalis Lietuvos gydytojų akušerių -ginekologų něščiujų darbo sąlygų aptarimą vertina subjektyviai. Tokia situacija siejama su tuo, jog Lietuvos teisès aktuose nèra detalios metodikos, kokia apimtimi reikètų domėtis néščiujų darbo sąlygomis.
2. Tyrimo rezultatai atskleide, jog yra tendencija išrašyti nedarbingumo pažymejjimus něščiosioms ne tik dẻl medicininių priežasčių. Tokiu atveju něščiujų problemos, susijusios su darbo sąlygomis, sprendžiamos nekeliant teisètų reikalavimų darbdaviams dèl tinkamų darbo sąlygų

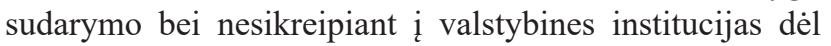
nėščiųjų teisių darbo santykiuose užtikrinimo.

3. Bendradarbiavimas su Valstybine darbo inspekcija nevykdomas, tačiau atskirais klausimais gydytojams akušeriams -ginekologams tai būtų naudinga (sprendžiant probleminès situacijas dèl néščiųų darbo kenksmingomis sąlygomis, taip pat informavimo ir konsultavimo klausimais).

4. Daugiau kaip pusè respondentų, spręsdami nedarbingumo pažymejjimo išrašymo néščiajai klausimą, susiduria su probleminemis situacijomis, kurios siejamos su sunkumais vertinat něščiosios poreikius ir objektyvius reikalavimus konstatuojant besilaukiančios pacientès nedarbingumą.

\section{Literatūra}

1. Dørheim SK., Bjorvatn B., Eberhard-Gran M. Sick leave during pregnancy: a longitudinal study of rates and risk factors in a Norwegian population. An International Journal Of Obstetrics And Gynaecology 2013; 120 (5) 521-530.

https://doi.org/10.1111/1471-0528.12035

2. Gustavsson $\mathrm{C}$, Kjeldgård L, Bränström R, Lindholm C, Ljungquist T, Nilsson GH, Alexanderson K. Problems experienced by gynecologists/obstetricians in sickness certification consultations. Acta Obstetricia et Gynecologica Scandinavica 2013; 92(9) 1007-1016.

https://doi.org/10.1111/aogs.12169

3. Hansen ML,Thulstrup AM, Juhl M, Kristensen JK, RamlauHansen $\mathrm{CH}$. Occupational exposures and sick leave during pregnancy: results from a Danish cohort study. Scandinavian Journal Of Work, Environment \& Health 2015; 41 (4) 397-406. https://doi.org/10.5271/sjweh.3507

4. Jurewicz J, Hanke W, Makowiec-Dabrowska T, Kalinka J. Heaviness of the work measured by energy expenditure during pregnancy and its effect on birth weight. Ginekologia Polska 2006; 77 (7) 537-542.

5. Katz VL. Work and work-related stress in pregnancy. Clinical Obstetrics \& Gynecology 2012; 55(3) 765-773.

https://doi.org/10.1097/GRF.0b013e318253b192

6. Larsson C, Sydsjö A, Alexanderson K, Sydsjö G. Obstetricians' attitudes and opinions on sickness absence and benefits during pregnancy. Acta Obstetricia et Gynecologica Scandinavica 2006; 85(2) 165-170.

https://doi.org/10.1080/00016340500430345

7. Lietuvos Aukščiausiojo Teismo Civilinių bylų skyriaus 2005 m. vasario mèn. 9 d. nutartis civilineje byloje Nr. 3k-3-92.

8. Lietuvos Respublikos sveikatos apsaugos ministro $1999 \mathrm{~m}$. 
lapkričio 29 d. įsakymas Nr. 515 „Dèl sveikatos priežiūros ịstaigų veiklos apskaitos ir atskaitomybès tvarkos". Valstybės žinios, 1999-12-03; 103-2972.

9. Lietuvos Respublikos sveikatos apsaugos ministro $2013 \mathrm{~m}$. rugsèjo 23 d. įsakymas Nr. V-900 „Dèl Něščiųjų, gimdyvių ir naujagimių sveikatos priežiūros tvarkos aprašo patvirtinimo“. Valstybès žinios, 2013-09-28; 102-5056.

10. Lietuvos Respublikos sveikatos apsaugos ministro $2008 \mathrm{~m}$. kovo 4 d. įsakymas Nr. V-170, Dèl Lietuvos medicinos normos MN 64:2008 „Gydytojas akušeris ginekologas. Teisès, pareigos, kompetencija ir atsakomybe்" patvirtinimo". Valstybès žinios, 2008-03-27; 35-1250.

11. Lietuvos Respublikos Vyriausybès 2015 m. gegužès 27 d. nutarimas Nr. 510 „Dèl Nėččioms, neseniai pagimdžiusioms ar krūtimi maitinančioms moterims kenksmingų darbo sąlygų ir pavojingų veiksnių sąrašo patvirtinimo". Teisès aktų registras, 2015-05-29; 8299 .

12. Miežanskienė R., Tartilaitė-Paulauskienè A. Nėščiųjų teisių ir garantijų igyvendinimas darbo teisiniuose santykiuose: Lietuvos valstybinių institucijų patirtis. Viešoji politika ir administravimas, 2016; 15 (3): 390-406.

13. Polańska K, Jurewicz J, MarcinkiewiczA, Makowiec-Dabrowska T, Hanke W. Medycyna Pracy 2014; 65 (1), 65-72.

14. Visuomenès sveikatos stebėsenos duomenų fondas. Medicinos personalas pagal apskritis bei savivaldybes 2006-2015, http:// sic.hi.lt/ (peržiūrèta 2016 spalio 03 d.)

\section{THE EXPERIENCES OF LITHUANIAN OBSTETRICIAN GYNAECOLOGISTS IN ASSESSMENT OF PREGNANT PATIENTS' HEALTH STATUS RELATED TO THEIR WORKING CONDITIONS}

A.Tartilaitè-Paulauskienè, R. Miežanskienè

Key words: obstetrician gynaecologists, pregnancy, working conditions.

Summary

The international research of scientists confirms, that proper identification of hazardous labour conditions during the visit to the obstetrician gynaecologist is exceptionally important to a pregnant woman the same as the foetus.

The aim of the research. The research is aimed at revealing the experiences of Lithuanian obstetrician gynaecologists in the assessment of the state of health of pregnant women in relation to their working conditions.

The description of research and its method. In order to achieve the purpose of the research, the survey was conducted in 2016 of November by sending an anonymous questionnaire to the members of two obstetrician-gynaecologists fellowships. The study involved 99 respondents out of 582 members involved in the fellowships activity.

The results of research revealed that more than 42 percent of respondents have been experiencing challenges while collecting the anamnesis of pregnant woman. Working conditions of pregnant woman had been discussed in details by 44,8 percent of the respondents; 43,8 percent of respondents indicated that the discussion of working conditions of pregnant women depends on the circumstances. More than 80 percent of respondents have confronted with internal conflicts while issuing sick leave certificates. More than half of the respondents while issuing a sick leave certificate to pregnant women were facing challenging situations.

Conclusion. A large part of obstetricians gynaecologists refers to their own judgement whether and to what extent to investigate the working condition of pregnant women. This situation is related to the fact Lithuanian legislator does not provide any detailed methodology for obstetricians-gynaecologists how and to what extent investigate what are the working conditions of pregnant patients. In some cases obstetricians gynaecologists are under the necessity to address the problems of non-medical nature, therefore the cooperation with the National Labour Inspectorate would be useful.

Correspondence to: ramune.miezanskiene@ktu.lt

Gauta 2016-11-30 